\section{Struggling for air}

\section{Robert Temple}

History of Science and Technology in Ancient India, Vol. II: Formation of the Theoretical Fundamentals of Natural Science. By Debiprased Chattopadhyaya. Firma KLM Private Ltd, 257B, Bepin Behari, Ganguly Street, Calcutta 700012, India: 1991. Pp. 593. Rupees 625.

THIS is more than a book on the history of science. It grapples directly with the issue of whether India is to have any future or not. Chattopadhyaya is a brave man, and he has tackled the fundamental problem head on: he shows the history of Hindu obscurantism that has suppressed the rise of science in India through the ages - the implications for the present are clear.

There were many brilliant early scientists in India, and it is in this book that we learn of them essentially for the first time. The author's historical spadework is breathtaking. He reconstructs the true story through the fog of the intervening religious fanaticism, and undoes the tangled knots of mangled texts brought about by the centuries of distortion and suppression. Westerners will be amazed to learn that human corpses were routinely dissected in India centuries before Vesalius (1514-64), as part of what Chattopadhyaya rightly calls ancient Indian "rationalist medicine". The relevant ancient text specifically calls for "direct personal observation". The original form of Indian Ayurvedic medicine was thoroughly and spectacularly rational. But its sad distortion, overlay and indeed perversion by religious fanatics has necessitated the use of Chattopadhyaya's own surgical skills in extracting the original glories of ancient Indian medicine from the mounds of rubbish in which it became embedded.

This is one of the saddest books ever written about the history of science. For never has a culture so satisfactorily stifled scientific progress as Hindu culture. The smug self-satisfaction of the devout - and they nearly won a recent election - has put a wet blanket over generation after generation of brilliant men of science. The Indian genius is there; but so is its nemesis. This book deserves to be read as a case history of how rationalism can be defeated repeatedly over the course of three millennia. There is no parallel in the annals of human thought.

Chattopadhyaya convincingly shows at great length that the scientist Uddālaka assruni antedated Thales of Greece and

\title{
Wounded civilization
}

AYURVEDIC medicine is in many ways still the medicine of millions. Yet it seems that all it had to offer the authors of the Hippocratic books was pepper for the eyes and a mouthwash for bad breath. As a system of medicine literally meaning 'knowledge of life', Ayurveda was incorporated into Hindu tradition as part of the fourth Veda, one of the ancient sacred books in Sanskrit. The system was based on two treatises composed in verse and prose by Charaka and Sushruta. Their dates, as with those of ancient Indian history in general, are woefully uncertain. Sushruta, for example, could have lived anywhere between $1000 \mathrm{BC}$ and $A D$ 1000. In The Healing Hand: Man and Wound in the Ancient World, Guido Majno returns to such original sources to unravel the history of the physician's art in the ancient civilizations of India, Greece, Rome, Egypt and China. With consider-

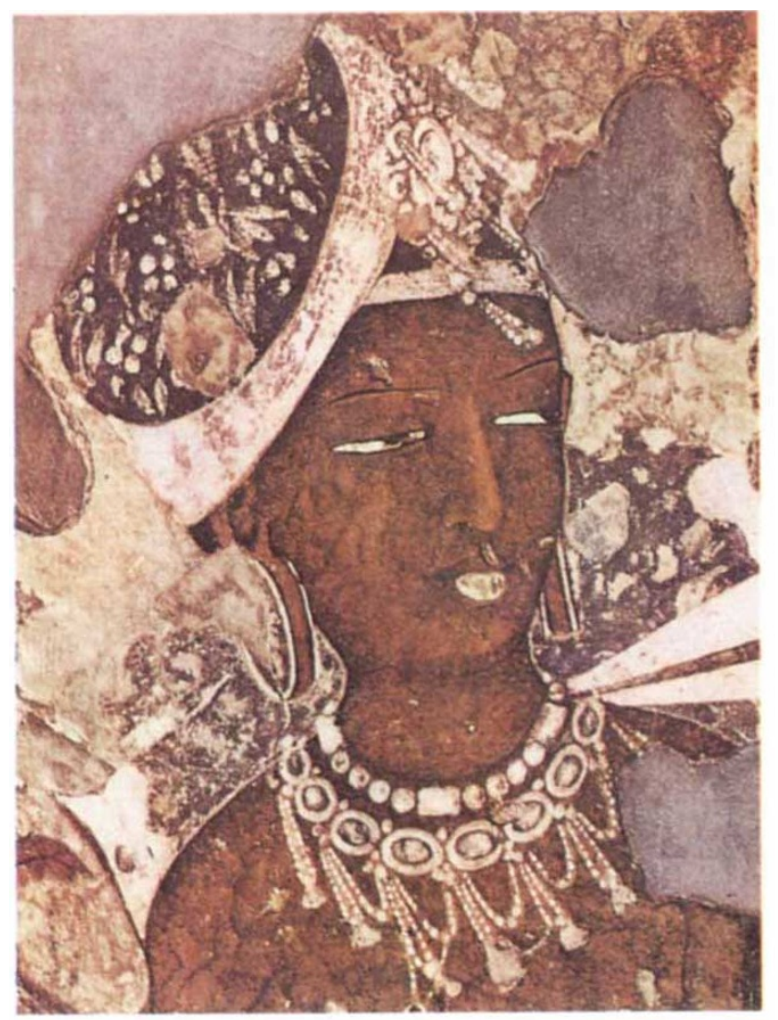
able verve, he reconstructs

case histories to see whether the patients were made better or worse by the treatments often putting ancient remedies to the test in his own laboratory. In one section he assesses the advice given by Sushruta to physicians who run into complications with pierced or stretched ears, a practice widespread in India owing to the protection it supposedly gave against "evil influences of malignant stars and spirits". This fifth- or sixth-century cave painting shows the stretched earlobes of a celestial nymph. In cases of "extreme pain and swelling", Sushruta's advice was to remove immediately the lint that stuffed the hole, anoint the infected part with a paste of honey and clarified butter enriched with barley and four herbs, wait for it to heal, then start all over again. Majno's panoramic book pinpoints beautifully those rare occasions in history when one great ancient civilization reaches out to learn from another. The book is to be issued in paperback by Harvard University Press on 26 September. Price is $\$ 19.95, £ 15.95$.

$\mathbf{P}$

that Indian science is older than Greek science. In the seventh or eighth century $\mathrm{BC}$, Uddālaka held to a position of "essentially a rational knowledge based on observation and even experiment". He believed that "everything is made of indivisible partless entities". He conceived "the basic stuff of the world as consisting of finest essence, of invisible minute particles". But more important, "instead of just proclaiming some theory or seeking any scriptural declaration as its main prop, he wants to demonstrate it on the strength of actual observation at every step".

In no other culture did atomism have a longer history. As Chattopadhyaya points out, "in the Indian tradition atomism was much more than a somewhat passing episode as it was in ancient Greece." $\mathrm{He}$ says: "The defence of atomism therefore specially in the nature-philosophy of the NyãyaVaiśesikas stretched over many centuries seems to be a unique feature of the scientific tradition of ancient India."
This is in stark contrast to China, where an atomic hypothesis never took root at all. As recently as the seventeenth century in India, the philosopher Gadadhāra on his deathbed uttered as his last words "Pîlu, pîlu, pillu", which means "Atoms, atoms, atoms". Thus, atomism was a traditional Indian hypothesis for more than 2,200 years.

This superb work of scholarship defies all summary. The author has rendered a service to all historians of science by opening up an unknown world - unknown even to his fellow countrymen. Let us hope that the lessons will not be lost on them.

If India continues to allow religion to have the upper hand over science, then the tales told by Chattopadhyaya will have sequels, and India will relapse into the Stone Age. That, frankly, is his message.

Robert Temple is at David Higham Associates Ltd, 5-8 Lower John Street, Golden Square, London W1R 4HA, UK. 